\title{
Hydrologic Analysis and \\ River-Quality Data Programs
}

River-quality assessment of the

Willamette River Basin, Oregon

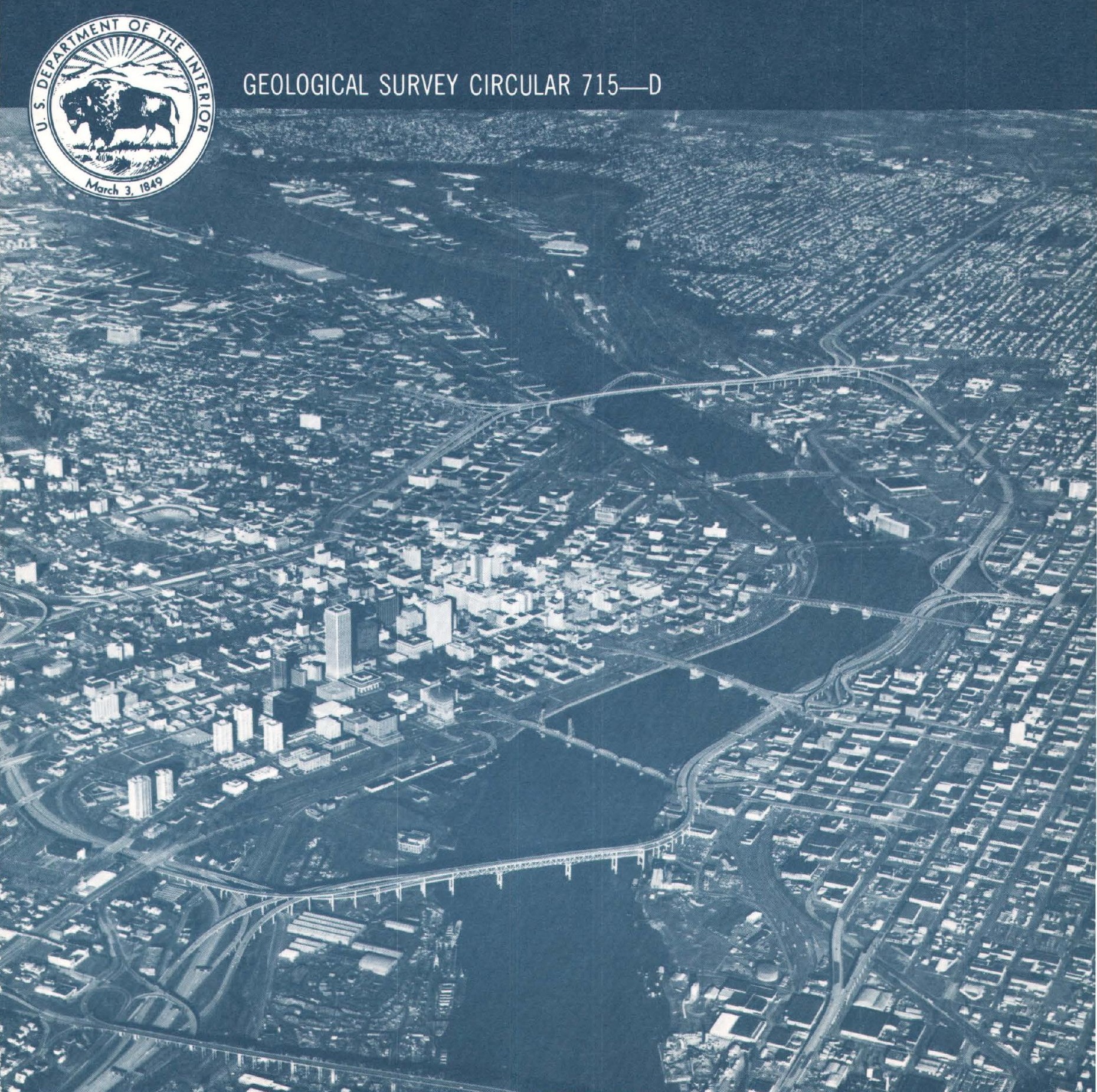





\section{Hydrologic Analysis and River-Quality Data Programs}

By Walter G. Hines, David A. Rickert, and Stuart W. McKenzie

RIVER-QUALITY ASSESSMENT OF THE WILLAMETTE RIVER BASIN, OREGON

GEOLOGICAL SURVEY CIRCULAR 715-D 


\section{United States Department of the Interior}

THOMAS S. KLEPPE, Secretary

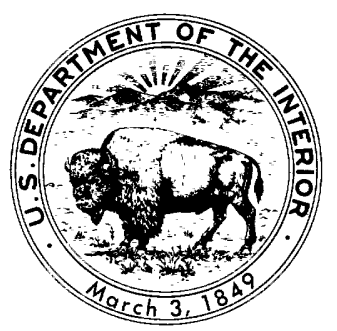

\section{Geological Survey}

V. E. McKelvey, Director

\section{Library of Congress Cataloging in Publication Data}

Hines, Walter G.

Hydrologic analysis and river-quality data programs.

(U.S. Geological Survey Circular 715-D)

Bibliography: p. 12.

Supt. of Docs. no.: I $19.4 / 2: 715-D$

1. Rivers-United States. 2. Water quality-United States. I. Rickert, David A., 1940joint author. II. McKenzie, Stuart W., joint author. III. Title. IV. Series: United States Geological Survey Circular 715-D.

QE75.C5 no. 715-D [GB1215] 557.3'08s [628.1'61]

$76-608289$ 


\section{FOREWORD}

The American public has identified the enhancement and protection of river quality as an important national goal, and recent laws have given this commitment considerable force. As a consequence, a considerable investment has been made in the past few years to improve the quality of the Nation's rivers. Further improvements will require substantial expenditures and the consumption of large amounts of energy. For these reasons, it is important that alternative plans for river-quality management be scientifically assessed in terms of their relative ability to produce environmental benefits. To aid this endeavor, this circular series presents a case history of an intensive river-quality assessment in the Willamette River basin, Oregon.

The series examines approaches to and results of critical aspects of riverquality assessment. The first several circulars describe approaches for providing technically sound, timely information for river-basin planning and management. Specific topics include practical approaches to mathematical modeling, analysis of river hydrology, analysis of earth resources-river quality relations, and development of data-collection programs for assessing specific problems. The later circulars describe the application of approaches to existing or potential river-quality problems in the Willamette River basin. Specific topics include maintenance of high-level dissolved oxygen in the river, effects of reservoir release patterns on downstream river quality, algal growth potential, distribution of toxic metals, and the significance of erosion potential to proposed future land and water uses.

Each circular is the product of a study devoted to developing resource information for general use. The circulars are written to be informative and useful to informed laymen, resource planners, and resource scientists. This design stems from the recognition that the ultimate success of river-quality assessment depends on the clarity and utility of approaches and results as well as their basic scientific validity.

Individual circulars will be published in an alphabetical sequence in the Geological Survey Circular 715 series entitled "River-Quality Assessment of the Willamette River Basin, Oregon."

J. S. Cragwall, Jr.

Chief Hydrologist 
Cover: Willamette River as it winds through Portland, Oregon. Photograph taken by Hugh Ackroyd. 


\section{CONTENTS}

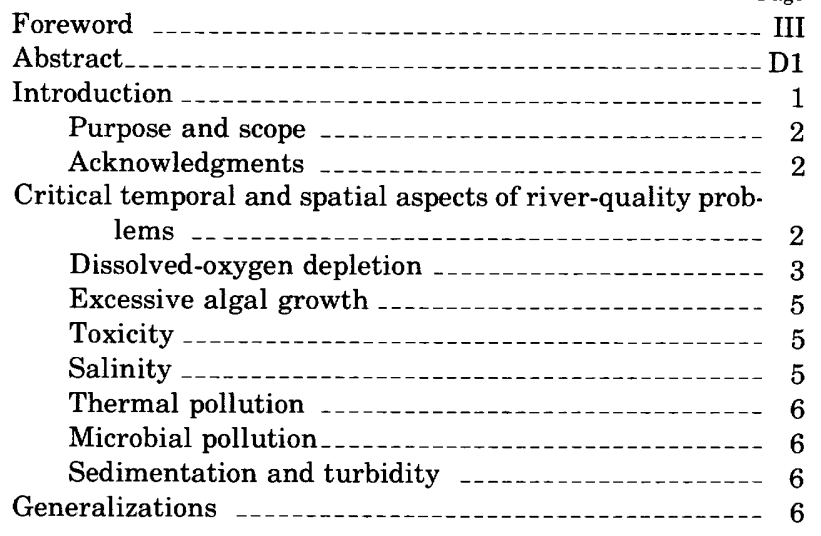

Foreword

Page

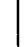

iscussion

The "shotgun" approach _.......... 7

An alternative to routine monitoring -..--_-_-_-- 7

Hydrologic analysis _....... 8

Reinterpretation of existing quality data _... 9

Repetitive synoptic studies _..._-_-_-_._- 9

Drought studies _..... 10

Flood studies _...

Summary --_---_-_-_-_-_- 11

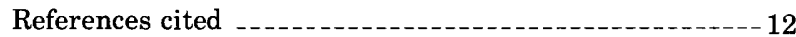

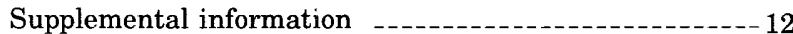

Quantification of river hydrology for quality analysis 12

Quantification of streamflow

Low flows -

High flows

Quantification of water temperature

Quantification of channel morphology _.......-17

\section{ILLUSTRATIONS}

Page

Figure 1. Diagram showing relation of immediate, generative, and extra environments to river-quality

2. Graphs showing Willamette River discharge at Salem, Oreg., 1944, 1964 and 1973 water years

3. Map of Willamette River basin, Oreg., emphasizing main stem, tributaries, and reservoirs

4. Sine curve for representing river temperature patterns

5. Graph showing mean monthly and maximum and minimum daily water temperatures for the North Santiam, Willamette, and South Yamhill Rivers, Oreg _

6. Seasonal pattern of surface water temperature for the Olentangy River, Ohio

7. Map and diagram representing the Willamette River, Oreg., showing distinctive morphologic reaches and elevation profile _..............

8. Cumulative time-of-travel for various low flows, Willamette River, Oreg

\section{TABLES}

TABLE 1. Selected characteristics of common river-quality problems

2. Lowest daily discharge for 7,14 , and 30 consecutive days in year ending March 31 for Willamette River at Salem, Oreg., 1910-70

\section{CONVERSION FACTORS}

[Factors for converting English units to the International System of Units (SI) are given below to four significant figures. However,
in the text the metric equivalents are shown only to the number of significant figures consistent with the values for the English
units]
English
in./s (inches per second)
$\mathrm{ft}^{3} / \mathrm{s}$ (cubic feet per second) (SI)
$\mathrm{RM}$ (river miles)
$\mathrm{mi}$ (miles)





\title{
Hydrologic Analysis and River-Quality Data Programs
}

\author{
By Walter G. Hines, David A. Rickert, and Stuart W. McKenzie
}

\begin{abstract}
In many basins it has proven difficult to use existing riverquality data for analysis of the temporal and spatial trends and the major cause-effect relations that control critical quality conditions. Major reasons for this problem are the arbitrary nature of sampling programs that generate the quality data and a general failure to account for the background variability in quality resulting from hydrologic phenomena.

A review of prominent river-quality problems of the $\mathrm{Na}$ tion's rivers shows that the timing, location, and frequency of occurrence of the problems are largely controlled by three hydrologic characteristics-streamflow, water temperature, and channel morphology. These characteristics show marked variation from river to river and, thus, must be systematically accounted for if river-quality data are to become more useful for interpretive purposes. An approach to river-quality data programs based on hydrologic analysis and repetitive synoptic studies is proposed as an alternative to current approaches that rely heavily on routine monitoring.
\end{abstract}

\section{INTRODUCTION}

Population growth and associated urban, industrial, and agricultural development have caused severe environmental stresses on the land and water resources of the Nation's river basins. An important aspect of long-range environmental planning is the understanding and quantification of man's impacts on the quality of rivers. Perhaps justifiably, in light of the complexities involved, enormous amounts of time, money, and effort are expended on river-quality sampling programs. In many basins, however, years of quality sampling have not generated adequate information from which to establish environmental standards or to make sound resource decisions. This situation has resulted in a growing dissatisfaction with riverquality data programs.

In a discussion dealing with water-quality sampling, Howells (1971, p. 166) said the following about existing monitoring practices:
A few monthly samples taken without regard to rainfall, stream flows, and vagaries in waste loads say very little about the quality of a stream, and it would be well to stop deluding the public that present monitoring systems mean very much at all. The time is long overdue for a good hard look at monitoring programs.

In a similar vein, Deininger (1974) stated:

Despite the fact that water quality monitoring programmes form the basis for all abatement and investment programmes, there is little evidence that they are being designed on a rational basis, rather they are designed on an ad hoc, emergency type, basis.

In a landmark paper on the quality of the $\mathrm{Na}$ tion's rivers, Wolman $(1971$, p. 905) cited a chronic inability to use available data for analyzing trends and cause-effect relations:

adequate comparisons of specific variables related to water and to river quality require systematic correlation with hydrologic behavior. Such correlations are rarely available . . . a knowledge of the "natural background" or temporal variability of a given parameter is often essential in detecting and measuring a trend. Statistically, a trend cannot be discerned unless it is possible to discriminate between the variability of the phenomenon as it might occur unaffected by the influences that one wishes to measure, in this case so-called pollution, and the variability normally associated with diurnal, annual, and significant secular climatic variations that occur in the hydrologic record over any period of time.

On the basis of experience with numerous rivers and estuaries in the United States, Velz (1970) concluded that a thorough understanding of the hydrologic regimen of rivers is an essential prerequisite for interpreting river-quality behavior and, thus, for formulating mathematical river-quality models.

The work of Howells, Deininger, Wolman, and Velz points to two prominent shortcomings in many quality sampling and analysis programs:

1. The arbitrarily derived, fixed temporal and spatial design of sampling programs from which quality data are derived. 
2. A failure to account adequately for the seasonal and reach-to-reach variability of river quality that results from hydrologic phenomena.

\section{PURPOSE AND SCOPE}

The purpose of this circular is to present ideas for improving the interpretive worth of riverquality data for environmental decisions. The main part of the circular covers two topics. The first deals with critical temporal and spatial aspects of seven prominent river-quality problems. Several important generalizations relating river quality to hydrologic phenomena are derived from this discussion. The generalizations form a framework for the second topic which is a discussion of deficiencies in recent river-quality data programs and the proposal of an alternative program for correcting the deficiencies.

The circular also contains a supplemental section ("Quantification of River Hydrology for Quality Analysis") that presents examples and methodologies useful for analyzing data on streamflow, water temperature, and channel morphology as a basis for river-quality studies. Though an admittedly incomplete treatment of the subject, the supplement serves to acquaint non-technical readers with the utility of hydrologic analysis and the origin of concepts developed in the main discussion.

Practical applications of the concepts presented herein are included in subsequent reports in this series on river-quality assessment of the Willamette River basin, Oregon.

\section{ACKNOWLEDGMENTS}

We wish to acknowledge the aid and encouragement of the Non-Federal Advisory Committee on Water Data for Public Use. Our special thanks go to the members of the Advisory Committee's Ad Hoc Working Group on River Quality Assessment. During the Willamette Study, the group included Howard B. Brown, Robert A. Canham, Edward J. Cleary, Laurence R. Jahn, John E. Kinney, Walter A. Lyon, John A. Roller, and Clarence J. Velz. The inspiration and insights of Clarence Velz were particularly helpful. Professor Charles E. Warren of the Department of Fisheries and Wildlife, Oregon State University, Corvallis, was instrumental in developing the "immediate environment" concept depicted in figure 1.

\section{CRITICAL TEMPORAL AND SPATIAL ASPECTS OF RIVER-QUALITY PROBLEMS}

The hydrologic character of a river basin is established through the complex interaction of "natural" and manmade features and activities. The results of these interactions are manifested in the quality of the rivers that drain each basin. Thus, every river has a unique hydrologic setting which to a large extent controls river-quality phenomena both in time and space. Because of this control, analysis of a river's hydrology should be a prerequisite to selecting an analytical method or identifying the data needed to assess any river-quality problem.

There are many hydrologically related factors that, depending upon the particular basin, can markedly affect river quality. Among these are solar radiation, air temperature, evaporation, precipitation, runoff, topography, geology, soils, vegetation, manmade developments, and landuse activities. Reports on river quality often include consideration of such characteristics. All too often, however, this consideration takes the form of a perfunctory physiographic description or geographic inventory. While interesting in itself, such information provides little insight into specific causal relations between hydrology and river-quality conditions. Rarely are the dominant hydrologic factors identified, understood, and adequately quantified to provide a framework for quality analysis.

The dominant hydrologic characteristics of rivers related to quality phenomena are streamflow, water temperature, and channel morphology (Velz, 1970). Together, these characteristics define the "immediate environment" of the river within which all river-quality processes occur and are controlled. (See fig. 1.) A thoughtful awareness and systematic accounting of this "immediate environment" is essential to understanding the behavior of river-quality processes and, axiomatically, for developing conceptually satisfying explanations about these processes.

Because streamflow, water temperature, and channel morphology are its primary elements, a river's "immediate environment" is in constant flux owing to seasonal and reach-to-reach changes in the hydrologic regimen. Over the annual cycle, this flux is so dynamic that it usually precludes the adequate definition of the "immediate environment" in a form suitable for detailed cause-effect explanation and quantification 


\section{EXPLANATION}

IMMEDIATE ENVIRONMENT-Has most direct impact on river quality; defined largely by streamflow, water temperature, and channel morphology.

GENERATIVE ENVIRONMENT-Most important to river quality during periods of land runoff; incorporates all hydrological and terrain properties of the river basin.

EXTRA ENVIRONMENT-Occasionally impinges on river quality; includes those factors which originate outside the river basin.

\section{EXTRA ENVIRONMENT}

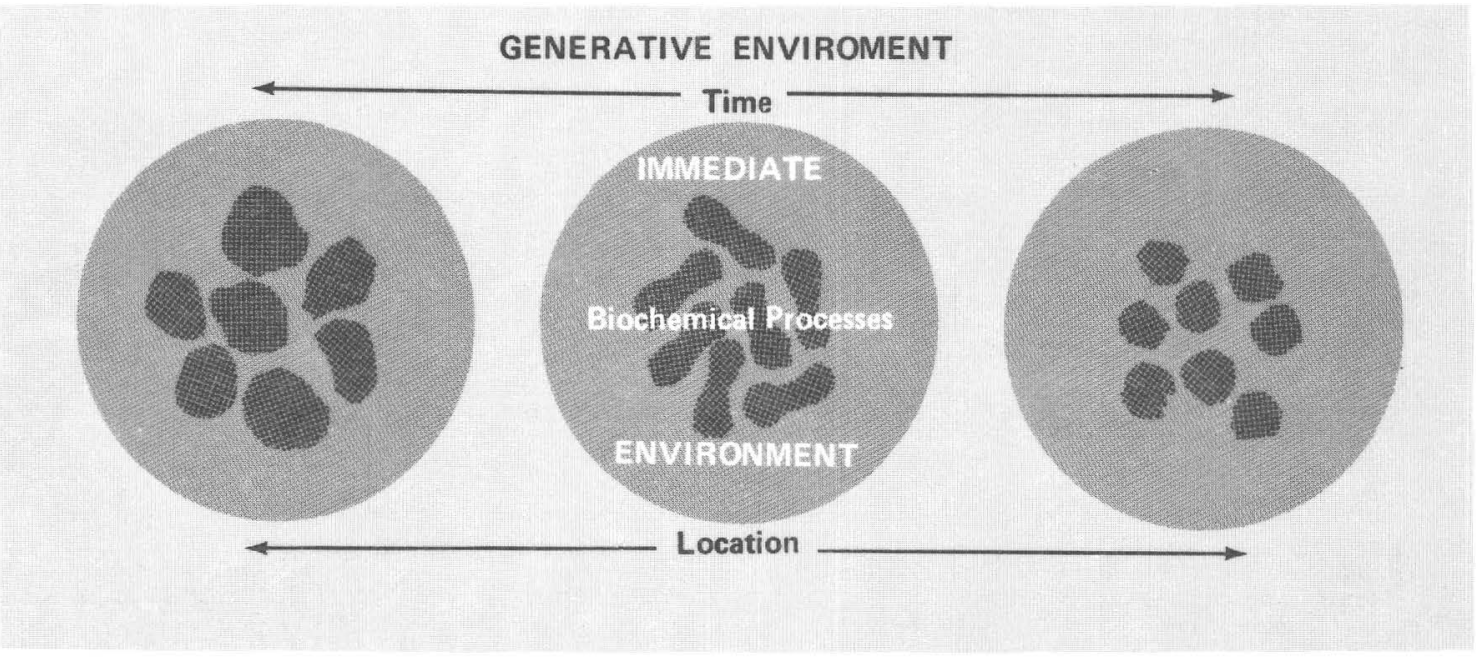

EXTRA ENVIROMENT

Figure 1.-Relation of immediate, generative, and extra environments to river quality. Changes in river quality commonly reflect alterations in biochemical processes that result from temporal and spatial changes in surrounding environments.

of river-quality processes. Therefore, a vital element of river-quality studies is the recognition of those seasonal periods when, and reaches where, (1) critical problems are most likely to occur and (2) hydrologic stability is sufficiently established so as to conform with the presumption of system equilibrium that underlies most methods of river-quality quantification.

Table 1 summarizes critical temporal and spatial aspects of seven common problems: dissolved-oxygen depletion, excessive algal growth, toxicity, salinity, thermal pollution, microbial pollution, and sedimentation-turbidity. Each problem results primarily from man's use of a river, but as indicated, the magnitude, timing, and place of occurrence are largely determined by the hydrologic controls of streamflow, water temperature, and channel morphology. Moreover, because of these hydrologic controls, river-quality problems often occur at times and locations far removed from their primary causes.

\section{DISSOLVED-OXYGEN DEPLETION}

During extended low-flow, high-temperature periods, the dissolved-oxygen (DO) concentration of river water is naturally lower than during other periods. This phenomenon relates to the fact that the solubility of oxygen in water declines with increasing temperature. Low-flow hightemperature conditions also favor long detention times, poor mixing, and temperature-induced increases in biological reaction. These factors, when coupled with heavy carbonaceous biochemical oxygen demand (BOD) loads from municipal and industrial wastewaters, can cause severe DO depletion in rivers, particularly in long, sluggish pools and tidal reaches.

During extended dry periods, waste debris from 
TABLE 1.-Selected characteristics of common river-quality problems

[The magnitude of problems and their temporal and spatial variability are largely controlled by definitive hydrologic characteristicsstreamflow, water temperature, and channel morphology. Brief complementary discussions of each problem are included in the text after the table]

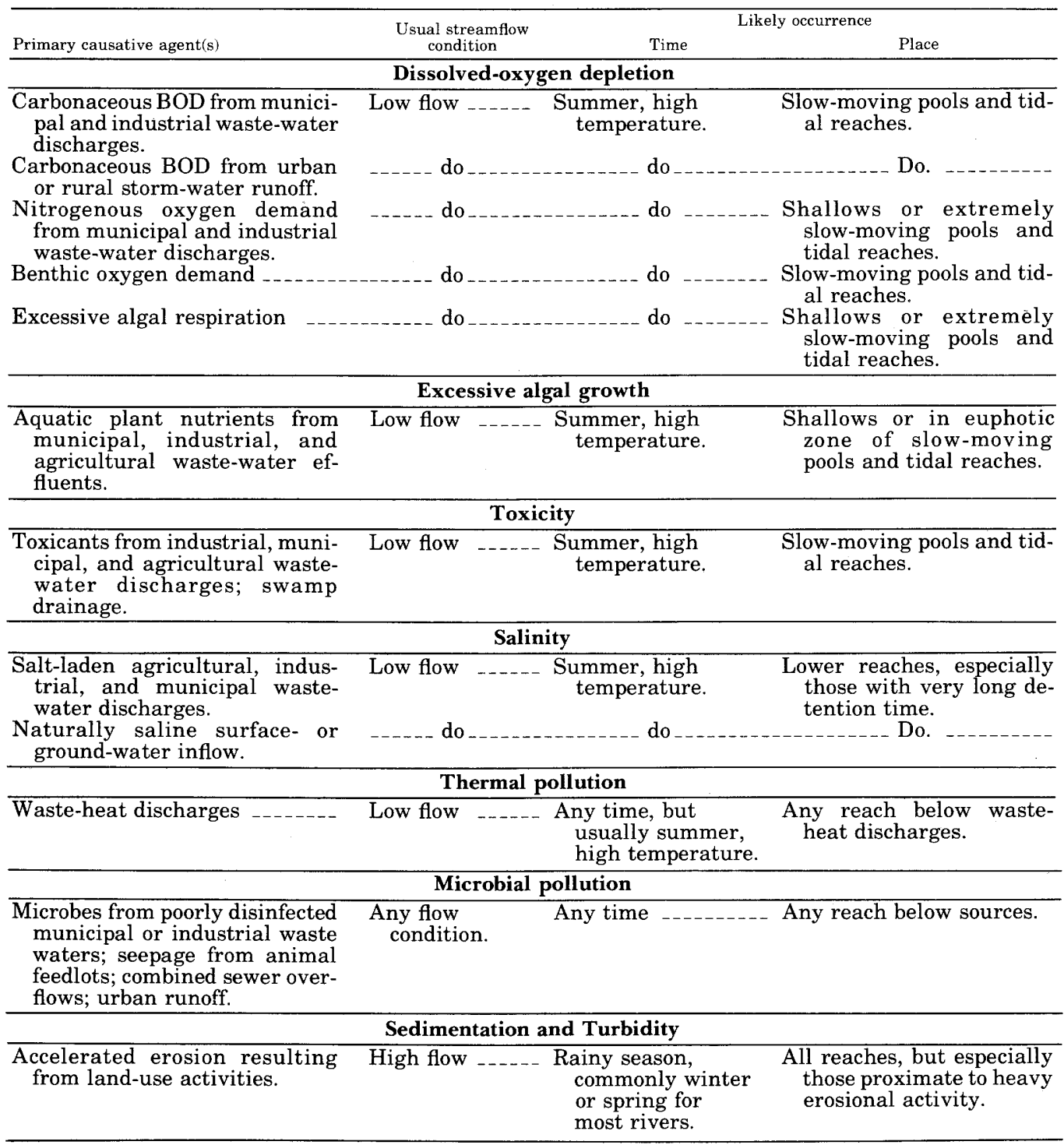

human activity and terrestrial plants accumulates in urban areas, rural agricultural land, and on other heavily vegetated land. Rainstorms during these periods can wash large quantities of oxygen-demanding organic debris into rivers at a time when the DO concentration is already low. A similar condition can occur downstream of municipalities having combined storm and sanitary sewers that overflow to the river during rainstorms.

Recent studies by Tuffey, Hunter, and Matulewich (1974) indicate that nitrification (the biochemical oxidation of ammonia to nitrite and nitrate by Nitrosomonas and Nitrobacter bacteria) may not be as prevalent in rivers as commonly assumed. They found that significant nitrification is almost always restricted to (1) shallow "surface active" reaches with good opportunity for attached growths of nitrifying bacteria or (2) long-detention-time pools, tidal reaches, and estuarine bays that have abundant suspended matter (also a surface phenomenon). Summertime water temperatures (near or greater than $20^{\circ} \mathrm{C}$ ) and significant ammonia sources are usually required for the nitrification process to exert a marked influence on the DO regimen. 
Reduced river velocity during low-flow periods allows increased settling and accumulation of organic sediments, particularly in depositional reaches such as pools and tidal reaches. These benthic deposits, usually resulting from the settleable-solids fraction of poorly treated municipal and industrial-waste discharges, can exert a high BOD duirng summer-high-temperature conditions.

Accelerated algal growth commonly occurs below nutrient sources during summer low-flow periods. Algal growth can have a marked effect on the river DO regimen. Often, large diel variations in $\mathrm{DO}$ are caused by daytime photosynthesis (DO production) and nighttime respiration (DO depletion), particularly in shallows and in the euphotic zone (zone of good light penetration) of slowmoving pools and tidal reaches. In addition, pools, and tidal reaches are prone to summer benthic oxygen demand caused by deposition and decomposition of dead algal cells.

\section{EXCESSIVE ALGAL GROWTH}

Large inputs of nitrogen, phosphorus, carbon, and other nutrients from municipal, industrial, and agricultural waste discharges can trigger accelerated algal growth in rivers. Rivers that receive high solar radiation are most prone to such eutrophication problems, usually during lowflow, high-temperature summer periods. During the colder months, most rivers do not exhibit excessive algal growths. However, during high-flow spring and winter periods erosion-transported nutrients can accumulate in depositional areas. These materials may not be effectively flushed before the low-flow season. In such situations the nutrients may remobilize and contribute to the growth of algae during the warmer, low-flow season.

Given a good supply of nutrients, long slowmoving reaches with high water temperatures and solar-radiation levels are the most likely places for planktonic (suspended) algal growth. Shallow reaches with good light penetration and a large streambed area for attached biological activity are optimal places for periphytic (attached) algal growth.

\section{TOXICITY}

Heavy metals, pesticides, and various organic and inorganic chemicals can be toxic to the life forms found in rivers. Toxic substances may also be a public health problem if ingested by humans in drinking water or in fish. If the toxic substances are dissolved in the river water, they can cause toxicity problems at any time of year and in any reach below their entrance into the river. However, many toxic substances (particularly metals and pesticides) are quite insoluble in river water and have an affinity for attachment to sediment. Thus, depositional reaches, as governed by the volume and velocity of streamflow and riverchannel characteristics, are most prone to chronic (long-term) toxicity problems. Benthic invertebrates, living in intimate contact with toxicantladen sediments or on rocks that are in constant contact with toxicants in overflowing water, are often the first organisms to exhibit quantifiable chronic toxicity. Because of long detention time (longer exposure to toxicants) and high water temperature which speed up biochemical processes (higher metabolic rates), summer low-flow periods are the most likely times for occurrence of toxicity problems.

Accidental oil spills, "batch dumps" of chemicals, and overflows from swamps are examples of situations that can cause acute (immediate) toxicity.

\section{SALINITY}

During low-flow, high-temperature periods, river waters naturally tend to become more concentrated with salts because of high evaporation, lack of dilution water, and consumptive use of water by phreatophytes. Thus, if salty waste waters such as irrigation return flows are discharged to the river during low-flow, high-temperature periods, high levels of salinity (dissolved solids) can result. Although high salinity can occur in any reach proximate to a salty waste-water discharge, the overall tendency is for salinity to increase in a downstream direction. This is because salts are conservative substances (that is, they do not appreciably degrade or change form with time). Highest salinity levels are, thus, commonly found in downstream river reaches or in large on-river reservoirs.

Rivers can have high salinity levels owing to saline ground-water inflows. If soluble saltbearing sedimentary minerals (carbonate, chloride, sulfate) are prevalent within a basin, the river can be naturally quite saline. Ground water, which often serves to sustain the low flow (base flow) of rivers in the arid southwestern United 
States, is in contact with these soluble minerals for long periods of time in many places. Thus many southwestern rivers are saline during summer months when flows are low and evaporation rates high. In such rivers, salinity levels may not show clear trends of downstream increase or decrease and are quickly changed by inflow of even small volumes of fresher water from tributaries, springs, or reservoir releases.

\section{THERMAL POLLUTION}

Thermal pollution can be described as an undesirable superelevation of a river's water temperature and is commonly associated with waste-heat discharges of condenser cooling water from fossil-fuel or nuclear power plants. Low-flow, high-temperature periods are particularly subject to thermal problems because fish and other aquatic animals may already be under natural thermal stress. However, in rivers where low-flow conditions occur during winter, waste-heat discharges can cause extreme temperature gradients or "thermal blocks" below outfalls.

Thermal pollution might also be considered in the reverse sense-that is, an undesirable depression of water temperature. Depressed water temperature may occur in reaches below thermally stratified reservoirs during summertime releases of cold bottom waters.

The water temperature below waste-heat outfalls and reservoirs tends to return to ambient levels at a rate governed by air temperature, solar radiation, wind velocity, relative humidity, and velocity and mixing of the flow.

\section{MICROBIAL POLLUTION}

All human and animal feces are potential sources of pathogenic bacteria and viruses. Because sources of pathogens are numerous and widely dispersed in any river basin, microbial pollution is a potential problem at almost any streamflow condition, place, or time of year. Therefore, the proximity of the source to the river and the speed with which microbes can be transported to the river are very important in analyzing microbial pollution problems. Low-flow problems most often result from the direct discharge of municipal, industrial, or septic tank wastes, or from urban runoff following rainstorms. Highflow problems commonly reflect contaminated overland runoff from urban and rural lands (espe- cially animal feedlots) and from hydraulically overloaded septic-tank fields. Municipal and industrial waste-treatment plants can also become overloaded because of sewer infiltration during storm periods and discharge large quantities of fecal microbes with the untreated sewage. On many rivers, the health risks of microbial pollution are greatest during the summer because of the increase in water-contact activities.

\section{SEDIMENTATION AND TURBIDITY}

Runoff from rainfall, particularly large storms that follow extended periods of dry weather, can transport large quantities of soil particles and organic litter into rivers. Some areas are naturally prone to erosion because of inherent physical characteristics (for example, steep slopes, poorly consolidated soils, lack of vegetal cover). Man's land-use activities, primarily those which cause widespread removal of vegetal cover and soil disturbance, increase erosion. Once the eroded material enters the river it is moved downstream. Depending upon the hydraulic regimen, defined largely by channel characteristics and the volume and velocity of streamflow, transported sediments will either stay in suspension, move along the bed (bedload), or be deposited in pooled reaches. High-flow conditions will cause smaller sized particles to stay in suspension, leading to persistent turbidity problems.

\section{GENERALIZATIONS}

The preceding table and discussion is not a comprehensive, in-depth description of riverquality problems. Indeed, a multichaptered treatise would be needed to do justice to this topic. The relevance of the table is that it allows recognition of several important generalizations that can be useful for improving the utility of river-quality data programs.

1. Most river-quality problems related to waste-water discharges are manifested during recurring seasonal periods of extended low streamflow and high water temperature. The problems are commonly most severe in slow-moving pooled reaches.

2. Problems associated with rapid biochemical activity (for example, nitrification and diel photosynthesis-respiration) occur most commonly during periods of extended low streamflow and high water temperature in shallows having bed material suited for 
abundant biological attachment and growth. 3. River-quality problems associated with erosion, sediment transport, sediment deposition, and turbidity are common during rainy, high-streamflow periods (particularly floods). These high-flow problems may also lead to biochemically related problems during subsequent low-flow periods, depending on the physical character of the river.

In applying these simple generalizations to specific rivers it should always be remembered that river developments and alterations such as reservoirs, navigation works, dredging, and water diversions can cause changes in the natural hydrologic regimen. Such changes can drastically affect the time and place of occurrence of riverquality problems. Fortunately, the generalizations can still be useful because valid analogies can usually be made between a river's natural and man-altered hydrology. For example, a reservoir or lock-and-dam navigation channel exhibits many of the same hydrologic phenomena (deposition of sediments and long detention time) as a deep slow-moving pool. Similarly, man may change the natural streamflow pattern of a river by water diversion or importation, and by reservoir release or storage. Despite such changes rivers often exhibit distinctive, recurring periods of high and low flow somewhat similar to those experienced under natural conditions.

\section{DISCUSSION}

To experienced hydrologists, limnologists, and water-resource engineers, the generalizations cited above may seem all too obvious and elementary. It is surprising, therefore, that such seemingly basic concepts have not been more widely applied either in the design or in the interpretive aspects of river-quality data programs. The reasons for this apparent paradox warrant some examination.

\section{THE "SHOTGUN" APPROACH}

National, State, and regional water-quality regulatory agencies have long faced a dilemma. On one hand, there is a need for river-quality information from which to develop tactics and strategies for water-resource and pollution management. In this case, the general goal is to obtain data suited to trend and cause-effect interpretation. On the other hand, water-quality standards dictate a need for data to check com- pliance with or violation of standards.

Faced with the dilemma of "what kind of data to collect?" the tendency has been simply to "shotgun it"- that is, to collect a lot of samples in a lot of rivers for a lot of constituents. Apparently, part of the rationale for this approach has been that once all the data are collected, compiled in books, or stored in computer files, "users" would decide as to their needs and then obtain the data for their particular purposes. Without a clear definition of goals and information needs, programs have typically become preoccupied with long lists of "pollution sensitive" variables. Seemingly, every year a few new variables are added to the list. Sampling frequencies for such programs are often selected arbitrarily or based simply on convenience. Sampling sites are commonly established by political boundaries, convenience, or proximity to a particular "polluter."

Because of the considerable activity generated during an era of growing environmental awareness, these large-scale programs have not been a popular subject of criticism. Indeed, it can be argued that many positive results have been forthcoming. Sampling methods have been markedly improved and standardized. Quality-control measures have been developed and emphasized. Data-handling capabilities, particularly computer-processing techniques, have been expanded and improved. New sampling and analytical hardware has been designed. Perhaps most importantly, the broad scope of environmental, economic, and social problems related to river quality has been more widely recognized. Despite these positive results river-quality data continue to be disappointing in terms of their interpretive utility, and criticism of data programs has mounted in recent years. As indicated in the "Introduction," there is a growing number of respected scientists and engineers who feel that programs based primarily on the monitoring-type approach will never prove efficient for trend or causal analysis. If this opinion is correct, and past experience indicates strongly that it is, the implications for environmental management can only be negative unless a more effective approach is developed and implemented.

\section{AN ALTERNATIVE TO ROUTINE MONITORING}

The basic framework of a new type of largescale river-quality data program is proposed here as an alternative to the prevailing approach. 
Under the proposed program, routine monitoring, long the heart of almost all large-scale programs, would be reduced in scope and relegated to its most useful functions: (1) a means of examining compliance with stream and effluent standards; (2) a screening device for identifying quality problems; and (3) a complement to in-depth, problemoriented studies.

The proposed program has three major elements:

1. A hydrologic analysis focusing on streamflow, water temperature, channel morphology, and basin history as a precursor to the design of sampling programs or the analysis of quality data.

2. The reinterpretation of existing quality data based upon their segregation into comparable temporal and spatial units as derived from element 1 .

3 . The design of river-quality sampling and analysis programs built upon recurrent, synoptic studies rather than routine monitoring.

\section{HYDROLOGIC ANALYSIS}

Hydrologic data on streamflow, water temperature, and channel morphology need not be exhaustively analyzed to form a basis for segregating and analyzing river-quality data. The fundamental concept is simply to identify the recurring seasonal periods of low and high flow and water temperature and to partition the river into its distinctive morphologic reaches.

The basic hydrology of most large rivers in the United States can be examined at this level of resolution with existing data. Knowledge of seasonal patterns of flow and water temperature can be obtained from a simple examination of a chronological series of hydrographs and thermographs (see figs. 2 and 5). Topographic or rivernavigation maps are well suited to compiling bed-slope profiles and, in conjunction with existing data on channel geometry and bed materials, can be used to section the river into distinctive reaches (or spatial units) (see fig. 7).

When conducted in concert with a review of river-basin history, the interpretation of hydrologic data allows recognition of major changes in the river system wrought by man (such as reservoir flow augmentation, dredging, or channelization). Chronological collations of hydrologic data in various tabular and graphical forms are help- ful for this purpose (see table 2). Statistical analyses of these historical data are invaluable for developing predictions such as recurrence probabilities for unusually severe low- and highflow events (droughts and floods). These severe events often foster critical quality conditions, rather than some "average" condition, that dictate the design of river-quality management strategies and facilities. For this reason, riverquality studies conducted during extreme conditions are particularly relevant for purposes of long-range planning. Results from such studies can form invaluable prophecies of future riverquality conditions and provide rarely available "end-point data" useful for predictions and comparisons.

An important aspect of the need for hydrologic analysis relates to the valid application of mathematics and statistics to the interpretation of river-quality data. Most mathematical formulations (even the so-called dynamic models) for describing river-quality phenomena are based on assumptions of system equilibrium. In the same vein, the application of statistics to river-quality data analysis is often based upon dubious assumptions of independence of observations and randomness of sampling errors. However, we have seen in table 1 that it is only within particular seasonal periods and within morphologically similar reaches of a river that river-quality phenomena can be expected to exhibit the homogeneous or stable ecological conditions that, even in the most optimistic sense, are suited to such mathematical and statistical assumptions.

In summary, hydrologic analysis gives the river-quality analyst a basic picture of how the river system operates in a seasonal and reach-toreach sense, how this system has changed with time, and finally, what sort of quantitative methods can be realistically applied to make interpretations. Without this basic framework the analyst is severely handicapped in trying to interpret quality data because he lacks working hypotheses, historical perspective, and valid quantitative methods by which to analyze variations inherent in the data. Lacking such essentials, analysts in the past have often relied heavily on methods involving statistical and computerized manipulations that are incompatible with hydrologic reality. In rare cases, where hydrologic data are poor, there may be few alternatives to this approach. However, in most large 
river basins in the United States where basic hydrologic records and historical documentation of river-control facilities are available, such arbitrary methods are both unnecessary and unlikely to generate reliable interpretations of trends or causal phenomena.

REINTERPRETATION

OF EXISTING QUALITY DATA

As described by Wolman (1971), many existing river-quality data have been examined for trends and cause-effect relations with disappointing results. We believe that many of these data can still be usefully interpreted, provided the data are amenable to segregation using river hydrology as the segregating tool.

An important concept in this endeavor is that the quality data should be subjected to interpretation by mathematical or statistical means only after the segregation step. The previously discussed generalities can be used as an initial guide, but the segregation procedure should also involve an analysis of antecedent hydrologic conditions, particularly streamflow and watertemperature patterns. Antecedent conditions partly determine whether one set of data was collected during a condition when the river's environment was similar enough to permit valid comparisons to be made with another data set.

For example, consider a set of DO readings obtained at a river station just following the spring snowmelt period at a flow of $10,000 \mathrm{ft}^{3} / \mathrm{s}\left(280 \mathrm{~m}^{3 / \mathrm{s}}\right)$ and a water temperature of $15^{\circ} \mathrm{C}$. These data are not comparable with DO readings from the same station taken in the fall at the end of a sustained period of low flow, even if streamflow and water temperature conditions were similar to those of the spring snowmelt period. In the case of the snowmelt period, the river environment is in a state of rapid chemical and biological transformation. Dissolved-oxygen readings reflect a confounding set of dynamic ecological interactions that exist only during a brief time. In contrast, the chemical and biological processes during the sustained low-flow period tend to be more nearly similar from day-to-day. Data from this period are, thus, ideally suited to segregation, analysis, and comparison with subsequent data from similar sustained low-flow periods that occurred in the past or that will recur in the future. In other words, quality data from one year can be made comparable to those from another year by nor- malizing the data using the seasonal stability of the river environment as the common denominator. With the data normalized, the impacts of man can be examined relatively independently of hydrologically induced seasonal variations of inriver processes.

For high flows, the normalization process is often more complex than for low flows because it involves an accounting of many antecedent variables and the consideration of the "generative," as well as the "immediate" environment (see fig. 1). These conditions are primarily a function of precipitation, extent of vegetal cover, erodibility of geologic and soil materials, and land-use patterns. Detailed real-time data for continuous quantification of these antecedent conditions is seldom available. Even if such data were available, a valid argument could be made for not using them all. That is, without a way of synthesizing the data, the analyst would soon be tired and confused by the sheer volume of information.

A practical compromise to this dilemma is first to obtain a general knowledge of basin weather patterns and terrain properties through field reconnaissance and study of existing climatic records, geologic maps, topographic maps, and interpretive land-resource reports. From such knowledge, inferences and hypotheses can be drawn as to how the general quality of land runoff (and, thus, the quality of the river) might vary, both temporally and spatially. From these general inferences and hypotheses, pertinent questions can be formulated and used in the process of segregating the high-flow river-quality data. For example: Were the data collected before or after leaf fall? Was the high flow caused by snowmelt or was it solely from rainfall? Was the ground saturated prior to the runoff event? Were the data collected at the lower end of a long pool that allowed sediment to be deposited before passage by the sampling site? How did reservoir operations affect the high-flow event and the transport of suspended materials? Answers to questions such as these can provide both a framework for segregating existing data and essential interpretive clues for analyzing trends and causal phenomena that had previously been overlooked.

\section{REPETITIVE SYNOPTIC STUDIES}

We propose that the interpretive core of riverquality data programs should be repetitive synoptic studies rather than routine monitoring. A 
synoptic study can be described as a river-wide (or multireach) study involving coordinated, intensive sampling over a short time period (several days to 1 or 2 weeks). Velz (1970, p. 400-421) terms these studies "short-term intensive stream surveys." A detailed discussion of synoptic studies is also presented by Kittrell (1969). The underlying rationale and advantages of the snyoptic study approach are described in the following discussion.

For most river-quality variables (or processes), synoptic study is the only means by which enough concurrent data can be collected within the river and its "immediate and generative environments" to obtain a reflection of the river as an integral, continuous system. Even with a well-designed study this reflection is imperfect and can be seen for only a brief period. However, subsequent studies made during similar hydrologic conditions allow meaningful comparisons to be made using a repetitive series of comparable data.

Unlike routine monitoring, synoptic studies allow sampling to be tailored to fit the needs of each particular river. This allows a concentration of effort on particular problems of interest, rather than the expenditure of effort on the collection of a few data on a large number of arbitrarily selected parameters. Also, because synoptic studies need be of only short duration, essential corollary information (for example, waste-water loading, reservoir-operating patterns, and solar-radiation conditions) can be obtained and processed with a minimum of effort. That is, one does not have to keep track of "everything" all year round.

Rather than the generation of data as an end in itself, problem-oriented synoptic studies foster interpretive-type reports. In contrast to compilations of monitor data, such reports contain qualitative descriptions and insights necessary for data segregation, causal analysis, and the development of generalizations relevant to all rivers. Thus, interpretive reports tend to develop an evolutionary pattern of analysis. This is vital because once gained and incorporated in a report, knowledge need not be "rediscovered" every 5 or 10 years.

An important, though often overlooked, aspect of data programs relates to the morale of the participants. Each of the authors has personally experienced (and sympathetically noted similar experiences in others) the dehumanizing, assembly-line feeling inherent with routine monitoring. These feelings stand in contrast to the feelings of purpose and curiosity that we and our coworkers experienced throughout the synoptic studies of the Willamette River, Oregon (Rickert and others, 1976).

The concept of synoptic studies is anything but new. They have been a basic tool of limnological and engineering study for many decades. However, they have seldom been employed on the repetitive basis that we propose and believe is required for fruitful analysis of pollution trends and cause-effect phenomena on a nationwide basis.

Viewed from the broadest perspective, then, a commitment to a nationwide program of synoptic river-quality studies would involve a shift to a more flexible, opportunistic approach, and away from a rigidly structured routine approach. Many different types of studies and interpretive methods would be necessary. Importantly, however, all studies would be bound by the common conceptual framework offered by the consideration of river hydrology and its intimate relation to each river-quality problem.

For purposes of illustration and discussion it is useful to talk in terms of two broad categories of river-quality studies. The first is the low-flow, high-temperature study, the second is the highflow study. For simplicity these are referred to respectively hereafter as drought and flood studies.

\section{DROUGHT STUDIES}

The overriding consideration in the execution of the drought study is the attainment of a reasonably stable streamflow and water-temperature regimen prior to and during sampling. A useful rule-of-thumb suggested by Velz (1970) is that stability should have preceded the study by a period roughly equal to the cumulative time-oftravel (at the prevailing low flow) of water through the reach under study. Often, the attainment of these stable conditions will involve waiting it out rather than beginning the study on some arbitrary date simply because "we had everybody ready." In some cases, if stable conditions are repeatedly interrupted by storms or other factors, cancellation of surveys or a shifting of goals (for example, to examination of stormrunoff loadings) may be in order.

The most intensive sampling would probably be needed in depositional reaches such as elongated pools and tidal reaches because these areas com- 
monly exhibit the most critical quality conditions. However, as implied in table 1, large diel variations in river quality are often associated with shallow "surface active" reaches. If these diel variations are the primary object of study, intensive around-the-clock sampling would be needed for short periods.

As implied above, spatial aspects of synoptic sampling design are a difficult subject for generalization, but a particularly relevant comment was made by Velz (1970, p. 402-403).

Ordinarily too many sampling stations are established with insufficient number of samples collected at any one. A few well selected locations with sufficient number of samples to define results in statistical terms provide a much more reliable profile of quality than many stations with only a few samples at each.

Besides the data on river hydrology that form the basis for the temporal and spatial design of the sampling program, corollary data as derived from one or several coordinated substudies will usually be needed. For example, a river DO study may require substudies to obtain corollary data on waste-water BOD loads, benthal deposits, periphytic and planktonic algae, nitrogen loads, light conditions, and anomalous reaeration phenomena related to structures such as lockand-dam navigation works.

\section{FLOOD STUDIES}

The overriding consideration in the study of river quality during flood conditions is a commitment to "chase" storms and keep reasonable records of land-surface conditions just preceding and throughout the normal seasonal period of high flow.

Synoptic sampling during floods is a difficult task that requires many trained people, tight organization, and good equipment. For these reasons exemplary flood-time river-quality studies have been rare in the past. However, increasing amounts of quality data are now being collected by the Geological Survey (and other agencies) during floods as an adjunct to the more routine streamflow and suspended sediment measurements. Synoptic quality studies would require more effort and better coordination and timing with these measurements.

In some cases, it may be necessary to sample bed materials before and after flood events. This is important because the movement and location of deposition of sediment-assoicated pollutants, rather than their concentration in river water at any one time, often controls the timing and magnitude of river-quality problems.

Remote-sensing data and synthesized, multifactor terrain-element maps are providing new tools for analyzing the land-surface conditions and erosional processes that control many highflow river-quality problems. The use of these new tools in conjunction with synoptic river sampling provides the potential to greatly improve the interpretive worth of river-quality data collected during flood periods.

\section{SUMMARY}

1. A host of hydrologically related characteristics in each river basin affect river-quality behavior at greater or lesser degrees of importance. However, a perfunctory mention or rudimentary inventory of these characteristics adds little to the analysis of riverquality data.

2. It is probably impossible, and it could be argued unwarranted and unnecessary, to attempt a quantitative accounting of all those characteristics of a river basin that impinge on river quality. We believe a rational, efficient approach is to concentrate on the quantification of those definitive characteristics of river hydrology that exert the most direct control on river-quality phenomena. These characteristics are streamflow, water temperature, and channel morphology.

3. From an analysis of streamflow, water temperature, and channel morphology, it is possible to predict the temporal and spatial character of most recognized river-quality problems. In other words, because of the overriding control exerted by river hydrology on quality, major problems will recur on a seasonal basis and tend to be most acute in particular types of reaches.

4. It is only within certain seasonal periods and distinctive river reaches that river-quality processes approximate (even remotely) the relatively stable ecological conditions necessary for the valid application of most of the statistics, biochemical equations, and models that are presently available to analyze quality data.

5. Most existing river-quality data have not proven useful for interpretive purposes. The 
existing data lack explanatory power because they are usually derived from routine monitoring programs that are poorly suited for documenting changes in river quality caused by hydrologic phenomena. Thus, the data cannot be adequately explained because they do not reflect the "immediate environment" that was responsible, in part, for the quality characteristics.

6. On the basis of the points cited above we contend that river-quality sampling and analysis programs can be dramatically improved through a deemphasis of the routine monitoring approach and added emphasis on the following:

(a) A competent analysis of the natural and man-controlled aspects of river hydrology as reflected by streamflow and water-temperature patterns and channel morphology.

(b) The reanalysis of existing quality data, after their segregation into compatible temporal and spatial units, as derived from the hydrologic analysis.

(c) The use of repetitive synoptic studies tailored to the environmental conditions and problems of interest in each river basin.

\section{REFERENCES CITED}

Chow, V. T., 1964, Handbook of applied hydrology: New York, McGraw-Hill, 29 chap.

Deininger, R. A., 1974, Optimization of water quality monitoring programs: Unpub. paper presented at the Internat. Symposium on Environmental Quality Monitoring, Division of Environmental Chemistry, Am. Chem. Soc., Los Angeles, Calif., April 2-4, 1974.

Foster, H. A., 1924, Theoretical frequency curves: Am. Soc. Civil Eng. Trans., v. 87, p. 142-203.

Gilroy, E. J., and Steele, T. D., 1972, An analysis of samplefrequency alternatives for fitting a daily stream-temperature model: Proc. Internat. Symposium on Uncertainties in Hydrol. And Water Resource Systems, December 1972, Tucson, Ariz., p. 592-608.

Gumbel, E. J., 1941, The return period of flood flows: Jour. Ann. Math. Statistics, v. 12, no. 2, p. 163-190.

Harris, D. D., 1968, Travel rates of water for selected streams in the Willamette River basin: U.S. Geol. Survey Hydrol. Inv. Atlas HA-273, 2 sheets.

Howells, D. H., 1971, Land use function in water-quality management: Water Resources Bull., v. 7, no. 1, p. 162170.

Interagency Committee on Water Resources, Subcommittee on Hydrology, 1966, Methods of flow frequency analysis: U.S. Govt. Printing Office, Washington, D.C., 42 p.

Kilpatrick, F. A., Martens, L. A., and Wilson, J. F., Jr., 1970, Measurement of time of travel and dispersion by dye tracing: U.S. Geol. Survey Techniques Water-Resources Inv., book 3, chap. A9, 25 p.

Kittrell, F. W., 1969, A practical guide to water-quality studies of streams: U.S. Federal Water Pollution Control Adm. Pub. CWR-5, 135 p.

Kothandaraman, Vecrasomy, and Evans, R. L., 1972, Use of air-water relationships for predicting water temperature: Illinois State Water Survey Report Inv. 69, 14 p.

Rantz, S. E., and Eakin, T. E., 1971, A summary of methods for the collection and analysis of basic hydrologic data for arid regions: U.S. Geol. Survey open-file report, $125 \mathrm{p}$.

Rickert, D. A., Hines, W. G., and McKenzie, S. W., 1976, Project development and data programs for assessing the quality of the Willamette River, Oregon: U.S. Geol. Survey Circ. $715-\mathrm{C}, 31 \mathrm{p}$.

Riggs, H. C., 1968, Frequency curves: U.S. Geol. Survey Techniques Water-Resources Inv., book 4, chap. A2, 15 p.

Shearman, J. O., and Swisshelm, R. V., 1973, Derivation of homogeneous streamflow records in the Upper Kentucky River basin, southeastern Kentucky: U.S. Geol. Survey open-file report, $34 \mathrm{p}$.

Tuffey, T. J., Hunter, J. V., and Matulewich, V. A., 1974, Zones of nitrification: Water Resources Bull., v. 10, no. 3 , p. 555-564.

Velz, C. J., 1970, Applied stream sanitation: New York, John Wiley and Sons, Inc., $619 \mathrm{p}$.

Willamette Basin Task Force, 1969, Hydrology: The Willamette Basin comprehensive study of water and related land resources, app. B, 5 chap.

Wolman, M. G., 1971, The nation's rivers: Science, v. 174, no. 4112 , p. $905-918$.

\section{SUPPLEMENTAL INFORMATION}

\section{QUANTIFICATION OF RIVER HYDROLOGY FOR QUALITY ANALYSIS}

\section{QUANTIFICATION OF STREAMFLOW}

Many rivers in the United States have stream-gaging records that are ideal for examining seasonal and extreme streamflow patterns and their relation to river quality. At stations with continually recording stream gages, the temporal variability of streamflow at a particular gaging site is uniquely defined by the hydrograph. Concurrently generated hydrographs from different gaging stations are useful for examining the spatial variability of streamflow. Depending on the objective of study, continuous, daily, or monthly hydrographs can be used to examine streamflow patterns. Available computer programs interfaced with the Geological Survey's surface-water data file, allow machine plotting of hydrographs for any time period for which records exist. (Information about the computer data file can be obtained through the Water Resources Division, U.S. Geological Survey, Reston, Va., 22092).

Figure 2 contains three hydrographs for the Willamette 

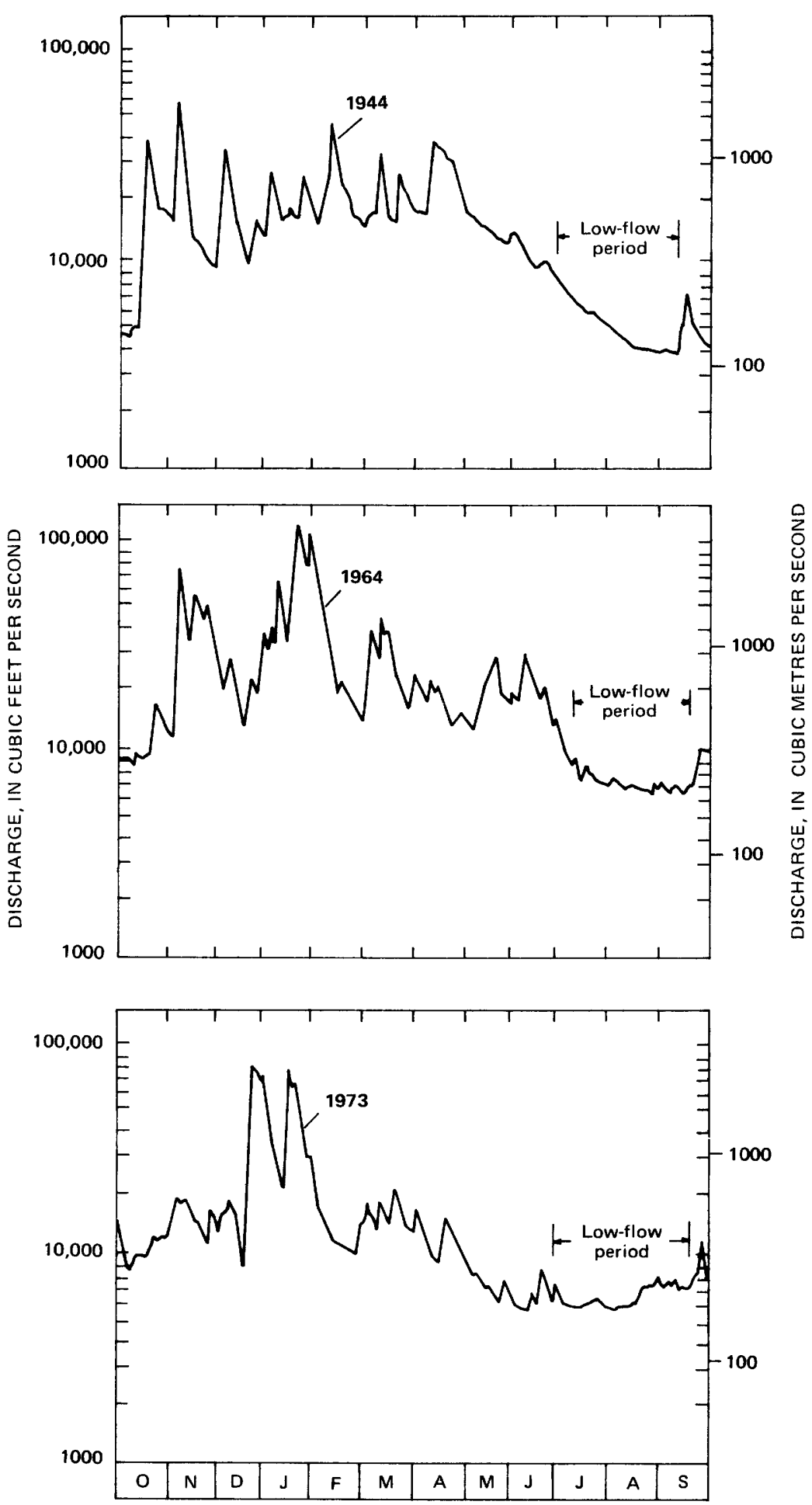

FIGURE 2.-Willamette River discharge at Salem, Oreg., 1944, 1964, and 1973 water years. Note the recurrent nature of the July, August, and September low-flow periods even after large-scale streamflow regulation began in 1953 . 


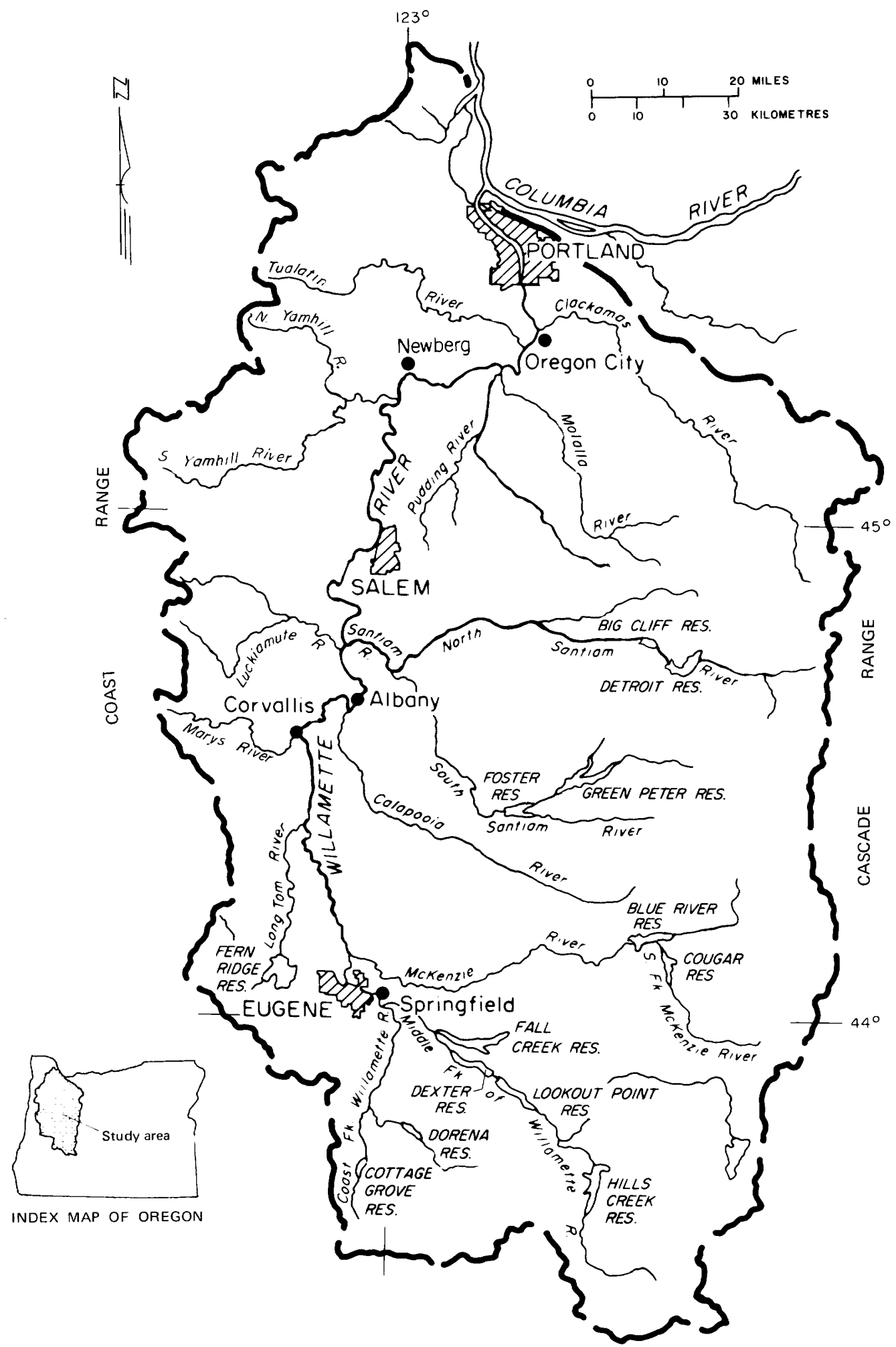

Figure 3.-Willamette River basin, Oregon. 
River at Salem, Oreg. for the water years 1944, 1964, and 1973. (See fig. 3 for basin map.) The 1944 hydrograph is repre-

TABLE 2.-Lowest daily discharge for 7, 14, and 30 consecutive days in year ending March 31 for Willamette River at Salem, Oreg., 1910-70

\begin{tabular}{|c|c|c|c|}
\hline \multirow[b]{2}{*}{ Year } & \multicolumn{3}{|c|}{ Lowest daily discharge in cubic feet per second } \\
\hline & 7 days & 14 days & 30 days \\
\hline & \multicolumn{2}{|c|}{ Period of minor low-flow regulation } & - \\
\hline $\begin{array}{l}1910 \\
1911 \\
1912 \\
1913 \\
1914\end{array}$ & $\begin{array}{cc} & 3,750 \\
& 3,750 \\
& 4,240 \\
& \end{array}$ & $\begin{array}{l}3,780 \\
3,800 \\
4,750 \\
4,360 \\
3,540\end{array}$ & $\begin{array}{l}3,850 \\
4,050 \\
5,020 \\
4,840 \\
3,640\end{array}$ \\
\hline 1915 & 3,420 & 3,480 & 3,500 \\
\hline $\begin{array}{l}1923 \\
1924\end{array}$ & $\begin{array}{ll} & 3,920 \\
& 2,990\end{array}$ & $\begin{array}{l}3,980 \\
3,070\end{array}$ & $\begin{array}{l}4,210 \\
3,160\end{array}$ \\
\hline $\begin{array}{l}1925 \\
1926 \\
1927 \\
1928 \\
1929\end{array}$ & \begin{tabular}{cc} 
& 3,020 \\
\hdashline & 3,130 \\
\hdashline & 3,730 \\
\hdashline & 3,190
\end{tabular} & $\begin{array}{l}3,070 \\
3,140 \\
3,730 \\
3,500 \\
3,190\end{array}$ & $\begin{array}{l}3,220 \\
3,190 \\
3,860 \\
3,560 \\
3,240\end{array}$ \\
\hline $\begin{array}{l}1930 \\
1931 \\
1932 \\
1933 \\
1934\end{array}$ & \begin{tabular}{cc} 
& 2,860 \\
$\cdots$ & 2,520 \\
\hdashline$-\cdots$ & 3,170 \\
\hdashline$-\cdots$ & 3,750 \\
$\cdots$ & 2,830
\end{tabular} & $\begin{array}{l}2,860 \\
2,580 \\
3,170 \\
4,020 \\
2,860\end{array}$ & $\begin{array}{l}2,920 \\
2,640 \\
3,170 \\
4,360 \\
2,900\end{array}$ \\
\hline $\begin{array}{l}1935 \\
1936 \\
1937 \\
1938 \\
1939\end{array}$ & \begin{tabular}{cc} 
& 3,140 \\
\hdashline & 3,080 \\
\hdashline & 3,250 \\
\hdashline$-1,940$
\end{tabular} & $\begin{array}{l}3,220 \\
3,090 \\
4,000 \\
3,270 \\
3,060\end{array}$ & $\begin{array}{l}3,350 \\
3,130 \\
4,110 \\
3,410 \\
3,170\end{array}$ \\
\hline $\begin{array}{l}1940 \\
1941 \\
1942 \\
1943 \\
1944\end{array}$ & \begin{tabular}{cc} 
& 2,520 \\
\hdashline$-\cdots$ & 3,140 \\
\hdashline$-\cdots$ & 2,980 \\
\hdashline$-\cdots$ & 4,200 \\
$-\cdots-\cdots-$ & 2,750
\end{tabular} & $\begin{array}{l}2,520 \\
3,210 \\
3,160 \\
4,300 \\
2,830\end{array}$ & $\begin{array}{l}2,570 \\
3,390 \\
3,220 \\
4,360 \\
2,880\end{array}$ \\
\hline $\begin{array}{l}1945 \\
1946 \\
1947 \\
1948 \\
1949\end{array}$ & \begin{tabular}{cc} 
& 3,170 \\
$\cdots$ & 3,650 \\
\hdashline$-\cdots$ & 3,400 \\
$\cdots$ & 3,670
\end{tabular} & $\begin{array}{l}3,300 \\
3,770 \\
3,940 \\
4,670 \\
3,730\end{array}$ & $\begin{array}{l}3,390 \\
3,830 \\
4,310 \\
4,880 \\
3,880\end{array}$ \\
\hline $\begin{array}{l}1950 \\
1951 \\
1952 \\
\end{array}$ & $\begin{array}{cr}4,100 \\
\cdots\end{array}$ & $\begin{array}{l}4,260 \\
4,200 \\
3,750 \\
\end{array}$ & $\begin{array}{l}4,610 \\
4,360 \\
3,980 \\
\end{array}$ \\
\hline \multicolumn{4}{|c|}{ Period of major low-flow regulation } \\
\hline $\begin{array}{l}1953 \\
1954\end{array}$ & $\begin{array}{l}\mathbf{5}, 320 \\
-160\end{array}$ & $\begin{array}{l}5,430 \\
6,290\end{array}$ & $\begin{array}{l}5,770 \\
6,560\end{array}$ \\
\hline $\begin{array}{l}1955 \\
1956 \\
1957 \\
1958 \\
1959\end{array}$ & $\begin{array}{cc} \\
\cdots\end{array}$ & $\begin{array}{l}6,160 \\
6,000 \\
5,440 \\
5,720 \\
5,440\end{array}$ & $\begin{array}{l}6,280 \\
6,150 \\
5,670 \\
5,830 \\
5,460\end{array}$ \\
\hline $\begin{array}{l}1960 \\
1961 \\
1962 \\
1963 \\
1964\end{array}$ & $\begin{array}{ll} & 5,510 \\
\cdots & 5,780 \\
\cdots & 5,7490 \\
\cdots & 6,470\end{array}$ & $\begin{array}{l}5,580 \\
5,800 \\
5,880 \\
5,650 \\
6,640\end{array}$ & $\begin{array}{l}5,680 \\
5,840 \\
6,090 \\
5,790 \\
6,740\end{array}$ \\
\hline $\begin{array}{l}1965 \\
1966 \\
1967 \\
1968 \\
1969\end{array}$ & \begin{tabular}{ll} 
& 5,360 \\
$\cdots$ & 5,030 \\
\hdashline & 5,840
\end{tabular} & $\begin{array}{l}5,400 \\
5,130 \\
5,340 \\
5,870 \\
7,360\end{array}$ & $\begin{array}{l}5,460 \\
5,290 \\
5,420 \\
5,950 \\
7,400\end{array}$ \\
\hline 1970 & 6,610 & 6,610 & 6,770 \\
\hline
\end{tabular}

${ }^{1}$ For example, the 1930 data are from April 1, 1929, to March 31, 1930. sentative of natural streamflow patterns while the 1964 and 1973 hydrographs reflect the impact of reservoir regulation. Regulation began on a large scale in 1953 (see table 2). Note particularly the recurrent nature of the July to September low-flow period and the effect that reservoir regulation has had on the low-flow regimen. The 1944 hydrograph (preregulation) shows a long recession in flow from April to September while the 1964 and 1973 hydrographs (postregulation) exhibit a more abrupt transition into a relatively steady lowflow period.

Other types of computer programs allow quick, relatively inexpensive tabulation and collation of useful streamflow characteristics. For example, table 2 summarizes the lowest mean daily streamflow values for the Willamette River, Oreg. for consecutive 7-, 14-, and 30-day periods for the period 1910-70. In this tabulation the effect of reservoir regulation depicted in Figure 2 becomes more quantifiable. Note, for instance, the marked increase in consecutive 30-day flows that have occurred since regulation began in 1953. Prior to 1953 the annual consecutive 30-day low flow ranged from 2,570 to $5,020 \mathrm{ft}^{3} / \mathrm{s}\left(72.8-142 \mathrm{~m}^{3} / \mathrm{s}\right)$ and averaged $3,670 \mathrm{ft}^{3} / \mathrm{s}\left(104 \mathrm{~m}^{3} / \mathrm{s}\right)$. Between 1953 and 1970 the consecutive 30-day low flow ranged from 5,290 to $7,400 \mathrm{ft}^{3} / \mathrm{s}\left(150-210 \mathrm{~m}^{3} / \mathrm{s}\right)$ and averaged $6,010 \mathrm{ft}^{3} / \mathrm{s}\left(170 \mathrm{~m}^{3} / \mathrm{s}\right)$.

\section{LOW FLOWS}

As described above, the quantification of a river's low-flow pattern should begin with a visual examination of hydrographs. Ideally, hydrographs from several gaging stations and from several years should be available for this purpose. The lowermost gaging station on the river is usually the most indicative of basinwide low-flow patterns.

In cases where virtually no streamflow data are available, regionalization techniques (Rantz and Eakin, 1971, p. 51) can often be effective for defining streamflow patterns. These techniques are based upon the transfer of streamflow data from gaged basins to nearby, physically similar ungaged basins. Streamflow regionalization can usually provide sufficient resolution to depict the general timing, duration, and magnitude of low flows, particularly if only general seasonal patterns are needed.

Depending upon the nature of the streamflow records and the river-quality problem in question, more quantitative methods of analysis may be warranted. This will likely be true in cases concerned with the design of intensive river-quality sampling and analysis programs intended to quantify temporal or spatial trends and pollution cause-effect relations. Quantitative low-flow analysis will also be needed to develop accurate time-of-travel information, to make estimates concerning phenomena such as atmospheric reaeration, and to make studies concerned with river-quality models and predictions.

For predictive analysis, it is useful to account for the magnitude and duration of low flows on a probability-of-recurrence basis. Such accounting permits the extrapolation of river quality observed under one low-flow condition to that which might be observed during severe drought conditions. Because many river-quality problems are associated with recurring low 
flows, the validity of these extrapolations can partly determine the success of river-quality planning and management decisions.

Statistical techniques are often applied to streamflow records to estimate the recurrence probabilities of low-flow events. Most techniques in common use by the Geological Survey and other Federal water resource agencies are based on either the "theory of extreme values" originally advanced by Gumbel (1941) or the probability theory of Pearson as summarized by Foster (1924) and Chow (1964, pp. 8-14 to 8-16). Velz (1970) has documented the use of Gumbel's theory for analysis of "drought flows." The Geological Survey utilizes a modification of the Pearson theory, known as the log Pearson Type III technique (Interagency Committee on Water Resources, 1966; Riggs, 1968) for analyzing the recurrence probabilities of both low and high flows. Using historical streamflow data stored on disks and tapes, computer programs are available for performing log Pearson or Gumbel probability analyses.

On intensively regulated rivers where regulation patterns change drastically from year to year, low flows may not be predictable from statistical interpretations. For such rivers, river regulation "rules," numerous hydrographs, and computerized data handling techniques are usually needed for quantitative analysis. For example, Shearman and Swisshelm (1973) have documented a streamflow-simulation model based on long-term streamflow data and reservoir-operating rules for a multiple reservoir system in the Upper Kentucky River basin.

Velz (1970) has described many of the basic considerations and data requirements for formulation of flow-simulation models of intensively regulated rivers. On the basis of studies in many regulated rivers, Velz analyzed the impacts on streamflow of hydroelectric plants, thermal powerplants, navigation works, flood-control works, irrigation, and diversions. Importantly, he stressed that the availability of statistical techniques and the computer does not preclude the need for thinking and a familiarity with the river in question.

\section{HIGH FLOWS}

As with low flows, the seasonal character of a river's highflow patterns can be examined through visual hydrographic analysis. In many basins, 3 or 4 years of streamflow record from a strategically located stream gage is sufficient to depict the general temporal aspects (timing and duration) of a river's high-flow season. Several stream gages and at least 3 or 4 years of record are needed to examine the spatial variability of high-flow patterns. Exceptions to this generalization occur in arid Southwestern basins where a distinctive high-flow season may not be evident.

After visual hydrographic analysis of general high-flow patterns, the hydrographs can be of direct use for segregating quality data through scrutiny of antecedent runoff conditions that existed prior to quality sampling. A series of antecedent analyses from several years of record and at several gaging stations provides a basis for evaluating temporal and spatial river-quality trends. If strong correlation exists between streamflow and a particular river-quality variable (for example, turbidity), more quantitative techniques can be employed as a precursor to cause-effect analysis and prediction. Quantitative techniques for predicting the recurrence probabilities of high flows, as is the case with low flows, are based largely upon statistical manipulation.

Gumbel's "theory of extreme values" or Pearson's probability curves are the methods by which high-flow recurrence probabilities are usually computed. Such statistical analyses are referred to as flood-frequency analyses. As is the case with drought-frequency analysis, computer programs are available for describing the magnitude, duration, and frequency of high flows. Computerized analysis of high flows should always be accompanied by a study of basin physiography and floodcontrol reservoirs.

\section{QUANTIFICATION OF WATER TEMPERATURE}

Many investigators, including Gilroy and Steele (1972), Velz (1970), and Kothandaraman and Evans (1972), have

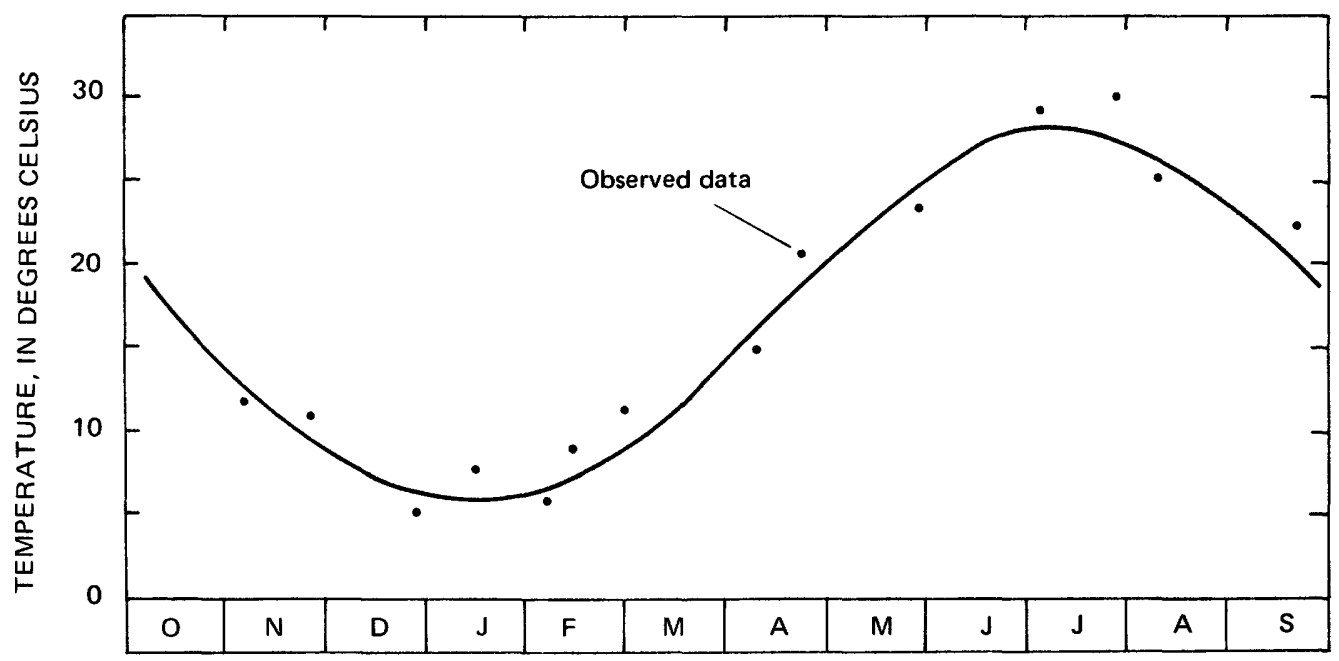

FIGURE 4.-Sine curve for representing river temperature patterns. 
noted and quantified the correlation between seasonal air-and water-temperature patterns. Further, Gilroy and Steele (1972) and Kothandaraman and Evans (1972) have proposed the use of a harmonic sine function (fig. 4) as an approximate model of river water-temperature patterns. For the many rivers that do not have extensive water-temperature data, such techniques can be used to derive seasonal water-temperature patterns.

On rivers with several years of water-temperature records, seasonal patterns usually can be easily recognized from thermographs; these are simple plots of weekly or monthly average water temperature versus time (see fig. 5).

If records of water temperature are fairly long ( $\sim 10$ years), statistical analysis can be used to establish the probability of extremes. Because the health of fish and other important aquatic organisms is often dependent upon maintenance of specified temperature ranges (rather than mean temperatures), the ability to estimate the probality of extreme temperatures is an important factor for river-quality planning and management.

An example of the use of a graphical statistical analysis of water-temperature patterns is shown in figure 6 . Note the identification of the "period of most severe drought flow." Concurrent examination of overlapping periods of critical streamflow and water-temperature patterns is a great advantage offered by such graphical presentations.
Many methods exist for the statistical analysis of watertemperature data, and readers desiring more discussion are referred to the references cited previously in this report. As is the case for streamflow data, the Geological Survey provides computerized storage, retrieval, and analytical tools for water-temperature data for many rivers in the United States.

\section{QUANTIFICATION OF CHANNEL MORPHOLOGY}

Data on slope, channel geometry, and bed material are the basic information for the quantitative description of the reach-to-reach variability of river channels. Perhaps the first objective in using these data for river-quality analysis is determination of the location and extent of pools and shallows. This objective can often be attained with readily available information augmented by some field measurements and observations.

The slope of a river can be examined with a simple graph of channel elevation versus river mile (for example, see fig. 7). Approximate slope profiles can be prepared directly from existing topographic maps by noting the elevation of contour lines which cross the river.

More precise definition of the slope profile and identification of pools and shallows requires channel-geometry measurements (width and depth) taken at various levels of streamflow. Such data are often available in the form of maps from the

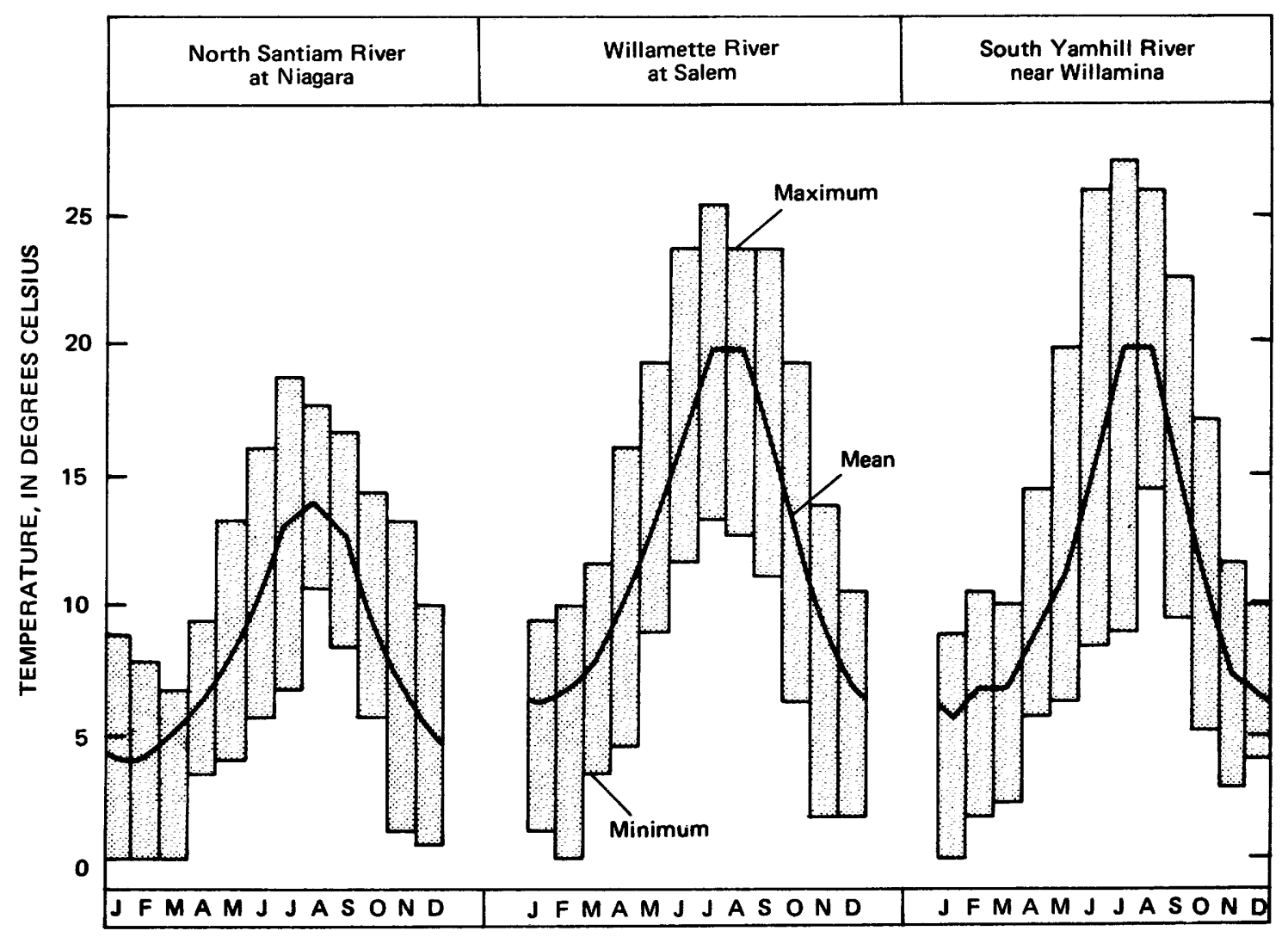

Figure 5.-Mean monthly and maximum and minimum daily water temperatures for the North Santiam, Willamette, and South Yamhill Rivers, Oreg. 


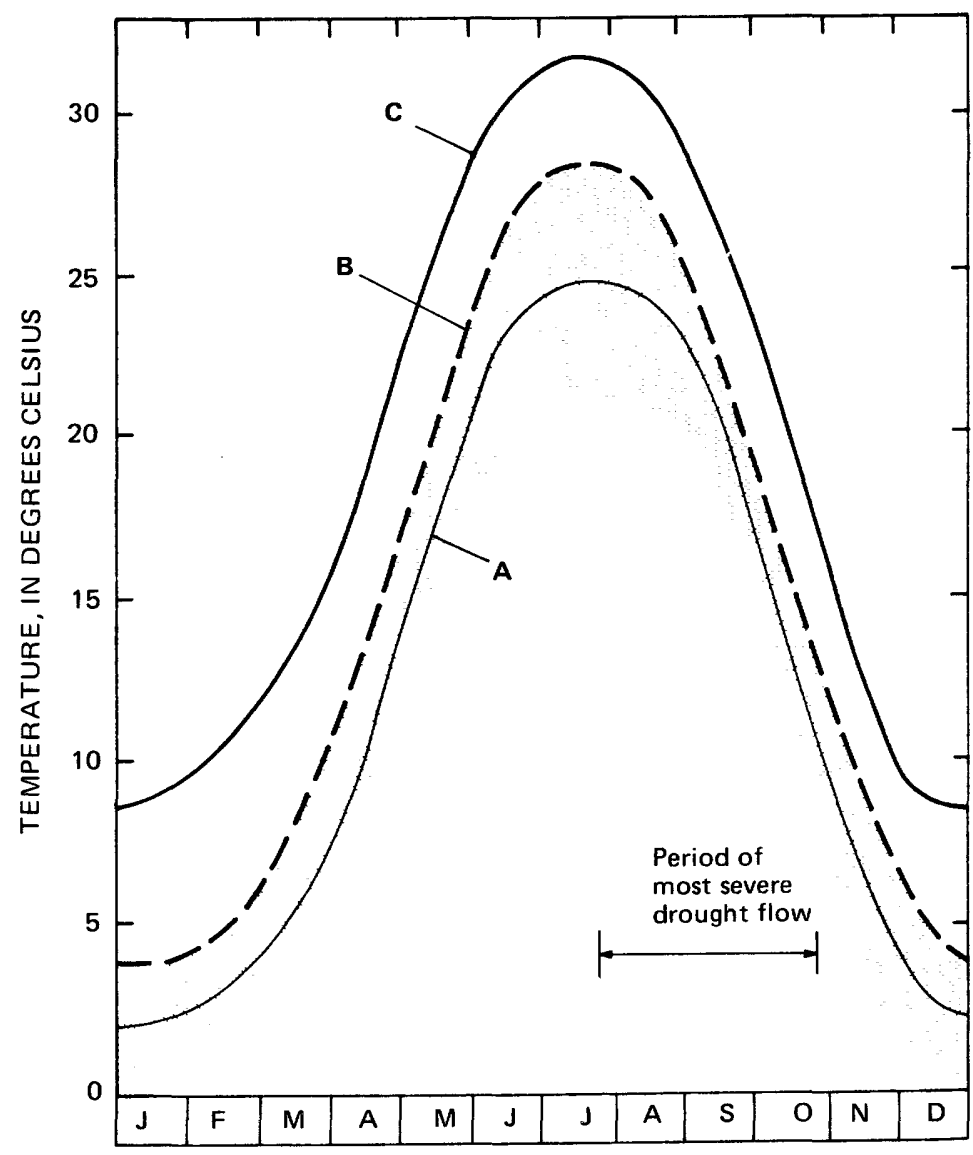

FiguRE 6.-Seasonal pattern of surface water temperature for Olentangy River at Delaware, Ohio. $A$, most probably monthly mean value; $B$, oncein-10 year monthly mean value; $C$, once-in-10 year maximum 3-day average; shaded area, range within which monthly mean can be expected in 80 percent of years. [Adapted from Velz, 1970, p. 72]

U.S. Army Corps of Engineers, the U.S. Coast and Geodetic Survey, the U.S. Coast Guard, or other agencies responsible for river navigation and regulation. In cases where channelgeometry maps do not exist or where channel changes have occurred since existing maps were prepared, a recording fathometer and boat can be employed to cross-section the rivers quickly and with suitable accuracy. When referenced to existing river-stage gages and streamflow data (to account for depth and width changes), channel-geometry maps can be used to calculate reach-to-reach time of travel on the basis of volumetric displacement. For estimating time of travel during high-flow conditions and in extremely shallow reaches, dye tests are recommended. Discussion relative to time-of-travel calculations by the volumetric-displacement technique is available in Velz (1970). Kilpatrick, Martens, and Wilson
(1970) have documented procedures for calculating time of travel from dye tests.

An example of a time-of-travel graph for the Willamette River, Oreg., as computed from channel geometry, river stage, and streamflow data, is shown in figure 8. Using such a graph, one can identify likely reaches of deposition or scour, calculate pollutant residence time from any known outfall location, and select sampling sites for optimal description of timedependent river-quality variables such as BOD.

The characterization of a river's bed materials is best accomplished by field observation and sampling. Several boat trips down the river, during which dredge samples, photographs, and visual observations are made, are usually sufficient to characterize the spatial distribution of bed materials. The bed materials should be examined for biological growths, 


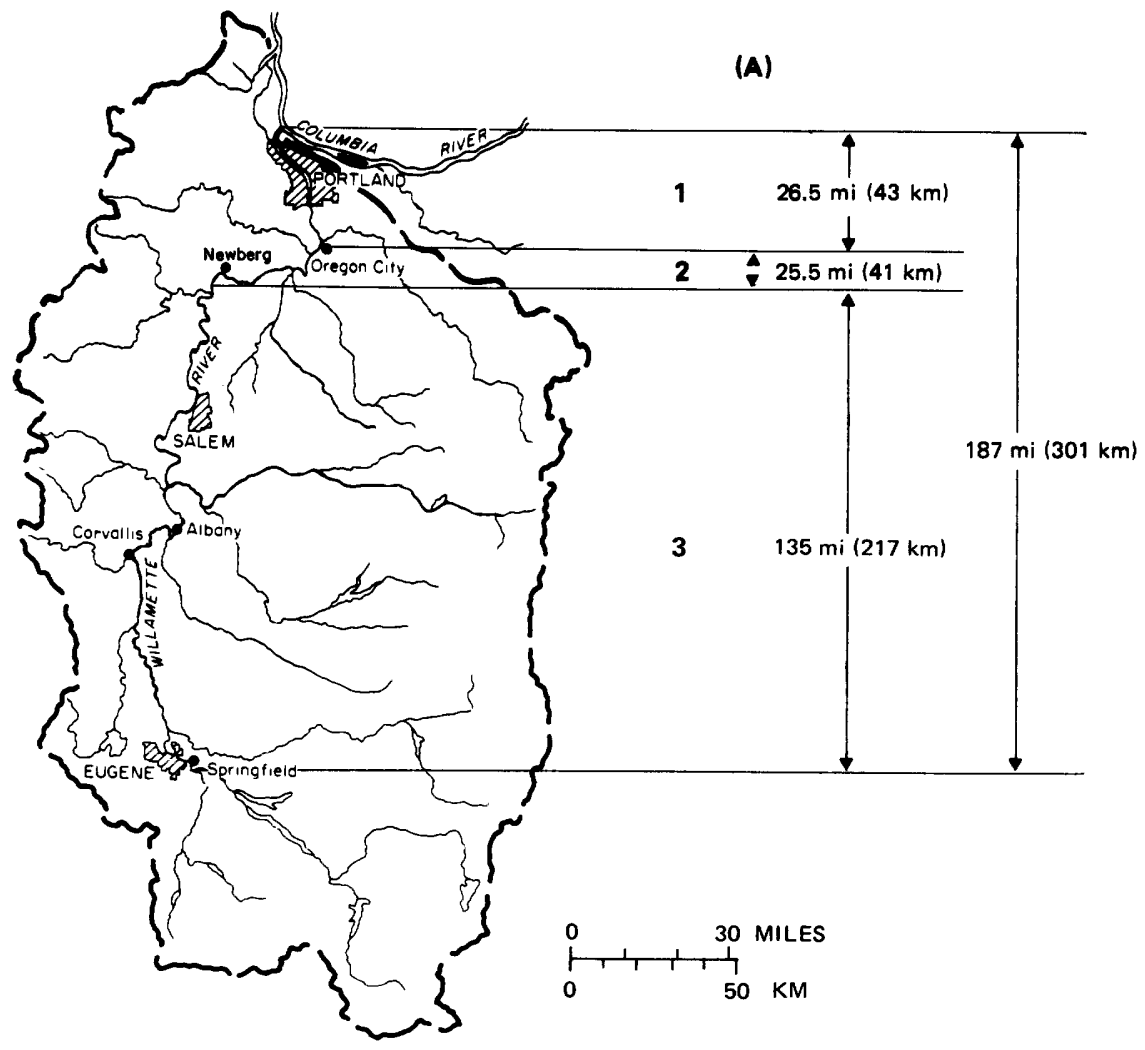

(B)

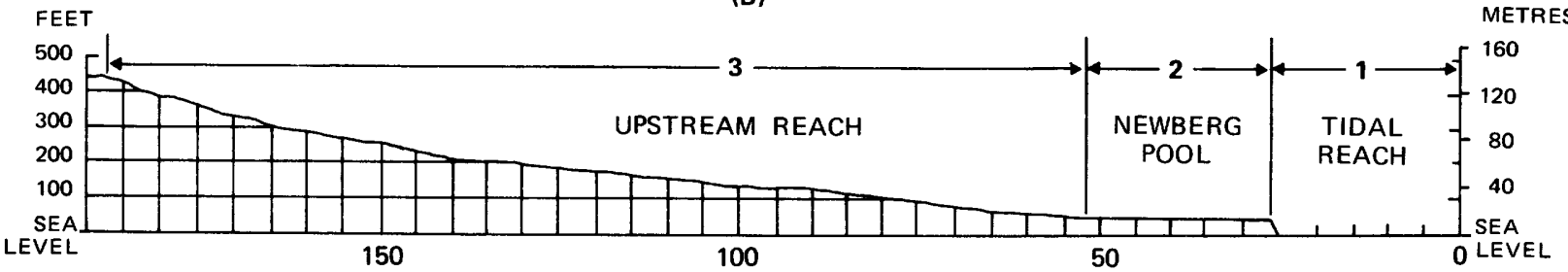

DISTANCE, IN RIVER MILES ABOVE MOUTH

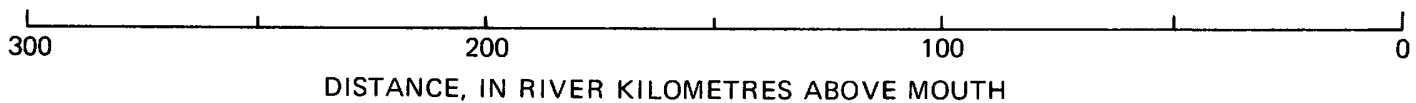

Figure 7.-Willamette River, Oreg., $A$, Distinctive morphologic reaches. $B$, Elevation profile.

color, and odor. Some form of size analyses may be warranted, depending on the objective. Care should always be taken to consider antecedent conditions, as floods or man-induced activities such as dredging can cause changes in the nature of bed materials.
In some cases, quantitative information on riverbed materials is available through the District Offices of the Geological Survey, particularly on rivers that are commonly sampled for suspended sediment and bed load. Agencies responsible for river navigation and dredging are also potential information sources. 
RIVER KILOMETRES ABOVE MOUTH

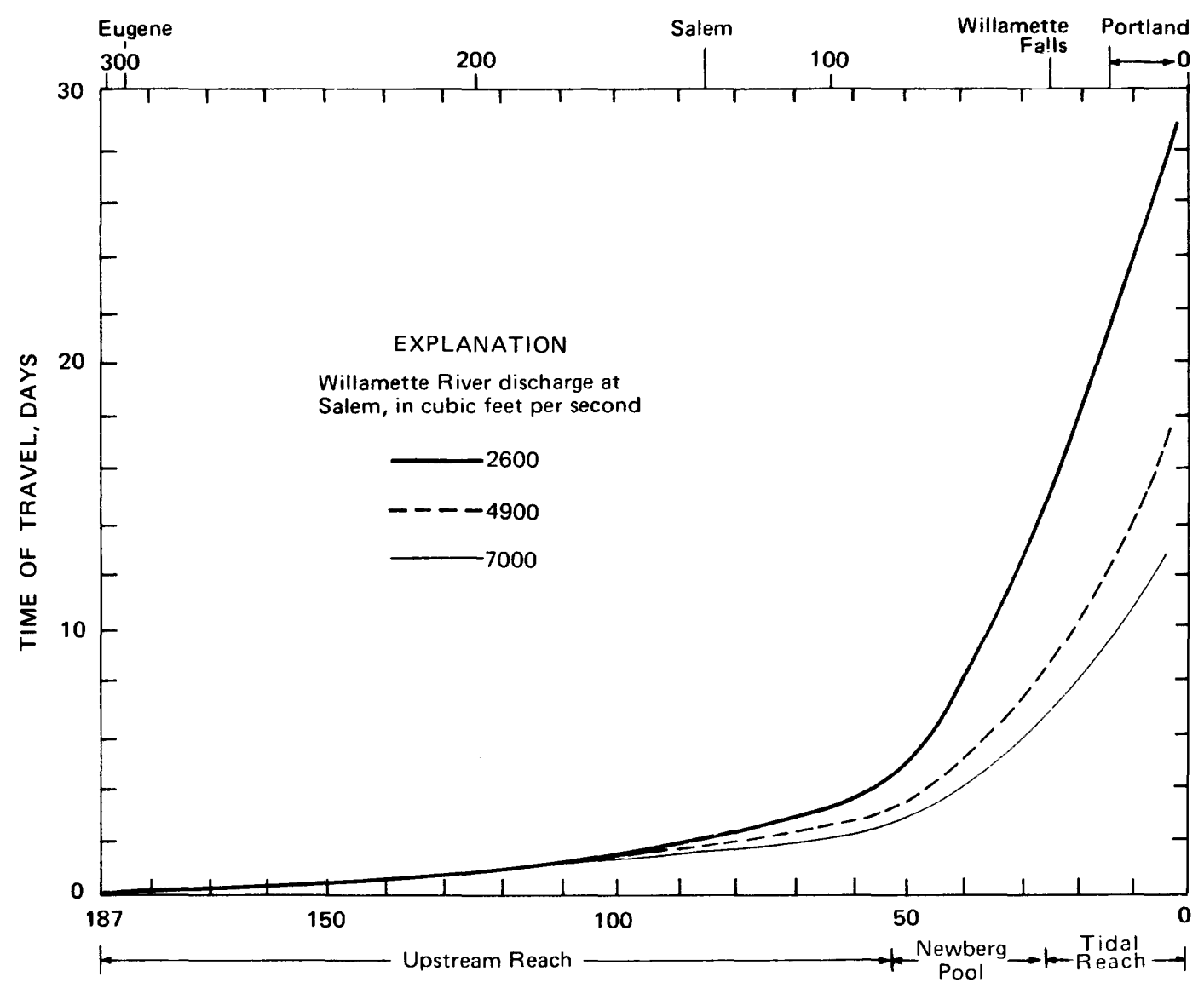

RIVER MILES ABOVE MOUTH

Figure 8.-Cumulative time of travel for various low flows, Willamette River, Oreg. 